\title{
EXPRESSIONS OF BELIEF AT PUSTÝ HRAD CASTLE IN ZVOLEN IN THE LIGHT OF SMALL METAL FINDS
}

\author{
NOÉMI BELJAK PAŽINOVÁ - RADOSLAV RAGAČ - JÁN BELJAK
}

\begin{abstract}
This paper discusses selected small metal finds linked with belief found at the medieval royal seat Pustý hrad (Deserted Castle) in Zvolen, Central Slovakia. As part of the latest research into the Upper Castle between 2016 and 2020, several dozen minor metal items were discovered, from which we will present specimens with religious motifs. Analysis of the selected examples of material culture brought information not only about the spectrum of forms and decorations of finds going back to the 13th-14th century but above all about their differences in meaning and types. In the form of discussion, we also reflect on the significant concentration of this type of metal finds in the Upper Castle around the peak platform near the flanking tower in the eastern line of the castle curtain wall and its possible role in crafts and money forging activities.
\end{abstract}

Key words: Slovakia - Pustý hrad (Deserted) Castle in Zvolen - High Middle Ages (13th/14th century) - small metal finds - belief-crafts/money forging activities.

\section{Prejavy viery na Pustom hrade vo Zvolene vo svetle nálezov kovových miniatúr}

Abstrakt: V príspevku sa zaoberáme kovovou miniatúrou s náboženskou tematikou objavenou na stredovekom královskom Pustom hrade vo Zvolene na strednom Slovensku. V rámci aktuálneho výskumu v areáli Horného hradu v rokoch 2016 až 2020 boli objavené desiatky kovových miniatúr, z ktorých predstavujeme jedince s náboženským motívom. Analýza súboru prináša poznatky nielen k druhovému zloženiu a variabilite motívov na týchto nálezoch datovaných do 13.-14. storočia, ale aj kodlišnostiam ich významov. Formou diskusie riešime výraznú koncentráciu tohto typu prameňa na vrcholovej plošine v blízosti veže vo východnej línii opevnenia hradu a poukazujeme na ich možnú úlohu pri remeselnej činnosti a peňazokazectve.

Kl'účové slová: Slovensko - Pustý hrad vo Zvolene - vrcholný stredovek (13./14. storočie) - kovové miniatúry - viera - remeselná/peňazokazecká činnost'.

A large collection of minor decorative items (fittings, mounts, badges), mostly dress accessories, of non-ferrous metals was discovered in the area of the Upper Castle of the royal Pustý hrad Castle in Zvolen between 2016-2020. The range of shapes includes quadratic, rectangular, oval motifs, various flowers, crescents, and hearts. They were used as appliqués on textile and leather clothing and costume as belt mounts, dress accessories, gimps and headgear in the High Middle Ages. The techniques and the process of reconstructing dress accessories step by step are explained in detail by L. Baračková (2014). The ambiguity of small metal finds is highlighted by the close intertwining of the religious and secular contexts, which was natural in the late medieval times. The secular symbolism is more diverse than that of their religious counterparts and refers to a broad spectrum of issues - from chivalry to sexuality (Sawicky 2014).

In Slovakia, no in-depth research into decorative small non-ferrous metal finds has been conducted and thus, there is no monograph or an article contribution published to-date. It should also be noted that individual items that have been presented in various publications are often without interpretation or analyses. In the past, a small assemblage of badges from Pustý hrad Castle in Zvolen was analyzed from the perspective of heraldry (Ragač 2001), but no other small metal finds, their meaning or function have been studied. On the other hand, we know from the surrounding countries numerous contemporary works devoted to (also) minor metal items in the light of production, representation, interpretation (e.g. Prokisch-Kühtreiber 2004; Hofer 2014; Sawicki 2014; 2017; 2018; Šlancarová 2018).

The main objective of this article is to explore the religious theme displayed on the small metal finds. Apart from the work of Slivka (2017), not much attention has been paid to this issue so far in Slovakia. Further goals of this study, although no less important, are more traditional 
archaeological issues related to the range of occurrence and their possible role in crafts and money forging activities at Pustý hrad Castle in Zvolen.

For people in the Middle Ages, metal miniatures with religious motifs provided - apart from decorative function - a spiritual experience from visits to distant sacral places, completed pilgrimages, they had protective functions e. g. during journeys and they were part of household religiousness (Bruna 2006). They were also associated with the environment of medieval religious brotherhoods common mainly in towns and with the developing literary culture (Bruna 2006; Gross 1999; Kubinyi 1999, 269-301; Nodl-Šmahel 2014).

The rich series of finds from Pustý hrad Castle in Zvolen is a unique assemblage from the perspective of typological composition and variability of motifs. Time is an important factor as well, as the analyzed collection can be reliably placed in a rather well limited period spanning the 13th and the first half of the 14th century. These facts make the collected assemblage even more unique and exceptional.

\section{Pustý hrad Castle in Zvolen (Fig. 1)}

The site of the NCM of Pustý hrad Castle in Zvolen in Central Slovakia itself is not extensively presented in this article, since the results of research activities from this important royal seat of the last rulers from the Árpád dynasty are regularly published in Slovakia (latest Beljak-Beljak Pažinová-Šimkovic 2018; Čierny-Beljak Pažinová-Beljak 2020; Hunka-Beljak Pažinová-Beljak 2021) as well as in foreign linguistic environments (latest Beljak Pažinová-Beljak 2020).

Although the strategic location of the Pustý hrad Castle hill was used in prehistory as well as protohistory, it acquired its important role thanks to medieval builders when kings of Hungary had a massive stone castle built whose area probably used the natural features of the site. The Upper Castle stood on the hilltop plateau (571 m a. s. 1.) as early as the 12th century. In the time of its greatest boom in the second half of the 13th century, its size was up to 3.5 ha. The Lower

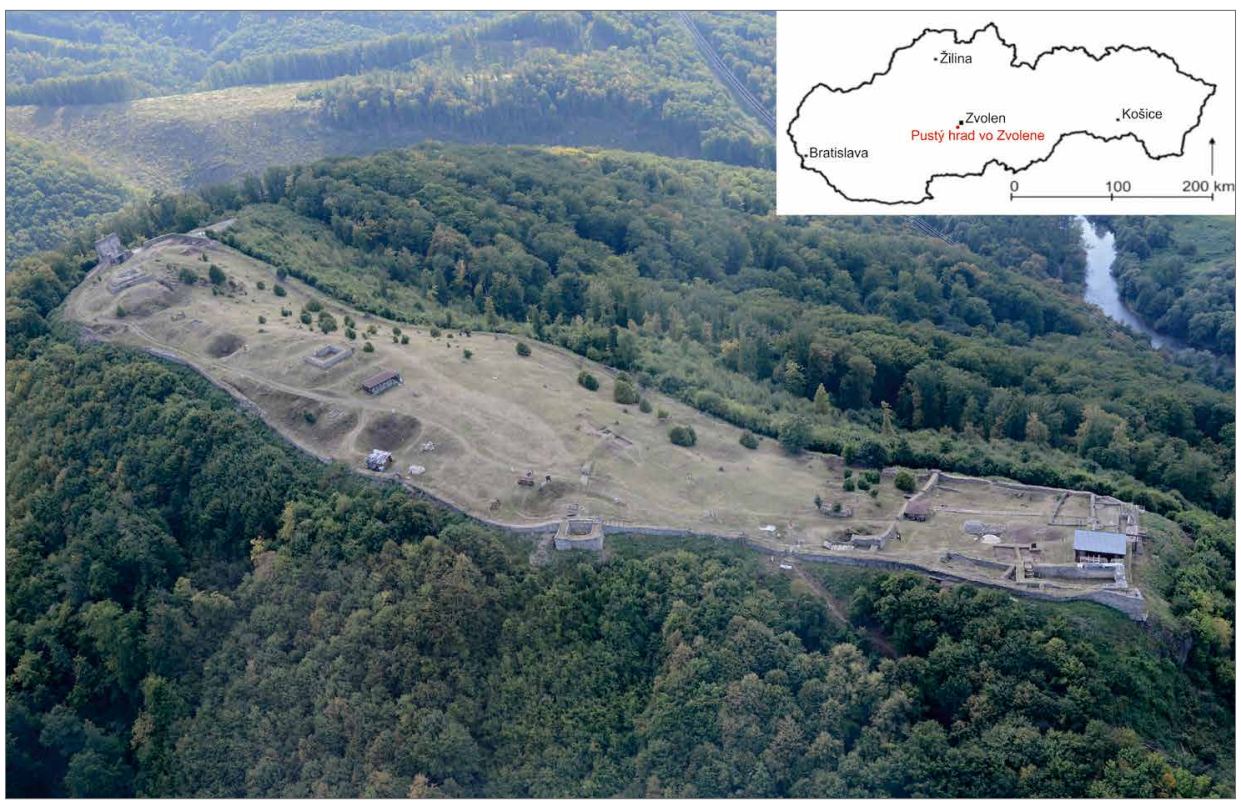

Fig. 1. Pustý hrad Castle in Zvolen. Aerial photo of the Upper Castle area. View from the east. Photo J. Beljak.

Obr. 1. Pustý hrad vo Zvolene. Letecký záber na areál Horného hradu. Pohl’ad z východu. Foto J. Beljak. 
Castle with an area of 0.7 ha was built in the lower part of the hill's jut (476 m a. s. 1.) (Beljak et al. 2014). The massive seat lost its function as a royal residence and fortification gradually in the first half of the 14th century. At the beginning of the 15th century, its function was not restored (Beljak-Beljak Pažinová-Šimkovic 2018, 19-28, 50-52).

The systematic archaeological excavations on the site started under the supervision of archaeologist V. Hanuliak, who worked at the castle between 1992 and 2008 and the beginning of the monument's renovation is associated with him as well. Since 2009, the research activities and renovation have been coordinated by the Institute of Archaeology of the SAS in Nitra and led by J. Beljak. Before 2015, exclusively the area of the Lower Castle was studied, with one exception in 2010 (Beljak-Beljak Pažinová-Kvietok 2015). Since 2015, when the massive cistern for rainwater at the Upper Castle was complexly studied (Beljak-Beljak Pažinová 2016; Beljak-Beljak Pažinová-Šimkovic 2016; Beljak Pažinová-Beljak 2016), the investigation activities have moved to the hilltop plateau again and they are still in progress. The longterm goal is not only to restore the castle as a monument but also to provide its protection, preservation and presentation for the present and future generations.

\section{Religious motifs on small metal finds (fittings, mounts, badges)}

The total number of minor metal items with religious motifs collected for the study is 34 . From the perspective of their information value, the fact that they are artefacts discovered by archaeological excavations in trenches in the Upper Castle between 2016-2020 is important (Fig. 2). Their places of discovery were as follows:

- near the entrance gate of the Upper Castle, beside the southern line of the curtain wall - trench 1/2019: two artefacts (one of them is a fitting with an inscription consisting of two fragments);

- on the hilltop plateau near the flanking tower in the eastern line of the curtain wall - trench 5/2016; 2/2017; 3/2017; 3/2019; 5/2019; 4/2020; 5/2020: thirty artefacts;

- on the lower terrace in a separate fortified part, outside the so-called Donč castle trench 5/2017: one artefact;

- in the courtyard in front of the entrance to the palace of the Donč castle - trench 6/2018: one artefact.

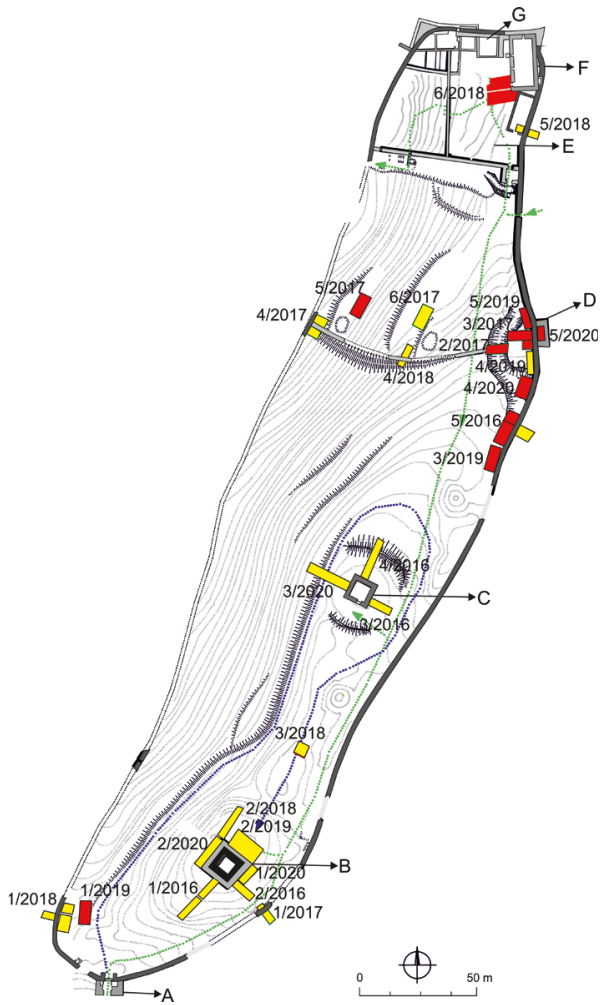

Fig. 2. Pustý hrad Castle in Zvolen. Situation plan of the archaeological trenches in the Upper Castle area: $\mathrm{A}$ - entrance gate, $\mathrm{B}$ - residential tower I (County Castle), $\mathrm{C}$ - residential tower II, D - flanking tower in the eastern line of fortification, $\mathbf{E}$ - the courtyard of the so-called Donč castle, $\mathbf{F}$ palace building, $\mathbf{G}$ - cistern for rainwater. Trenches studied in 2016-2020 indicated by colours: yellow - without finds of small metal finds with religious motifs, red - with these motifs. Drawing N. Beljak Pažinová.

Obr. 2. Pustý hrad vo Zvolene. Situačný plán archeologických sond v areáli Horného hradu: A - vstupná brána, B - obytná veža I. (komitátny hrad), C - obytná veža II., D - veža vo východnej línii opevnenia, E - nádvorie tzv. Dončovho hradu, F - budova paláca, G - cisterna na dažd'ovú vodu. Farebne vyznačené sondy skúmané v rokoch 2016 až 2020: žltou farbou bez a červenou farbou s nálezmi kovovej miniatúry s náboženským motívom. Kresba N. Beljak Pažinová. 
The typology of religious motifs on small metal finds from the Upper Castle is defined as follows:

- The basic Christian symbol - the cross - is represented by three artefacts.

- A saint's attribute is represented by one artefact.

- Marian motifs were most frequently represented: the symbol of the rose was predominant (16 specimens), the less frequent motifs included fleur-de-lis (5 specimens), heart (6 specimens) and crescent ( 2 specimens). A Marian symbol was also present through a fitting with an inscription.

\section{The cross}

The most significant Christian symbol, the cross, can be found in a stylized form of two miniature fittings with arms. The pair is almost identical in shape (one from trench 5/2016 and the second one from trench 4/2020), one of which is slightly damaged. They are small equal-armed crosses (Figs. 3:1,2), the arms' ends are widened into three juts. Concerning their small size, the juts are only schematic. Moreover, they are like the clover cross or the fleur-de-lis cross. Relief ribs reinforce the cross's arms from the inside, and an attaching rivet was in the middle. A simple engraved St. Andrew's cross with a small cross inserted in its middle was found at the Upper Castle also on a bronze plate ring (Fig. 3:4) discovered in trench 4/2020. The collection contains also a small decorative bronze fitting with a rivet (Fig. 3:3) in the shape of the swastika as a holy symbol. It was discovered during the sieving of the trench 3/2017 fill. In the Middle Ages, we find this type of hooked crosses mainly in heraldry. St. Andrew's crosses also had an overlap into the mundane environment. Saint Andrew had a specific importance as the patron saint of women eager to get married and of a good marriage (Rulíšek 2005). Therefore these crosses often appeared also on artifacts that were gifted out of love.

\section{Marian motifs}

In the Middle Ages, the Marian worship gradually evolved into several forms - such as the contemplative Virgin Mary with a child, pieta, a helper, or theological dispute over her immaculate conception (Rapp 1996, 105-108). The subtle fitting (Fig. 3:16) in the shape of a wavy rimmed banner ( $5 \mathrm{~cm}$ long, $2 \mathrm{~cm}$ wide) with two miniature perforations in the middle of the shorter sides' rims is the most important representative of the Marian motifs. The fitting was found in the southern part of the castle area, near the main entrance gate in trench $1 / 2019$. Its shape is directly inspired by medieval book paintings or murals where they are common. Along the rims of the banner is a relief rope design and a short German inscription hILF is in the hallmark area. The first letter of the inscription is minuscular, the other three letters are majuscules. The use of minuscule in combination with majuscule emphasizes the archaic character of the inscription created in the first decades of the 14th century. The patch undoubtedly had its content pendant with the inscription "maria". The war cry "Maria hilf" was widespread during the crusades in the second half of the 13th century and is associated with the French king Louis IX Saint (PätzoldWeissbecker 2006). Its content is related to the newly originating cult of the Virgin Mary, Helper of Christians. This find is unique also from the perspective of the domestic medieval written culture. Currently, it is the oldest known German inscription from the territory of Slovakia. Other German epigraphic monuments in the local environment emerged as late as the beginning of the 15th century (Šedivý 2019).

In a wider context the motifs of stylized (heraldized) flowers, roses, and lilies can also be associated with the very popular Marian motifs in the Middle Ages. In general, flowers symbolize the beauty of creation, life as well as its transience (Royt-Šedinová 1998, 79). However, their 

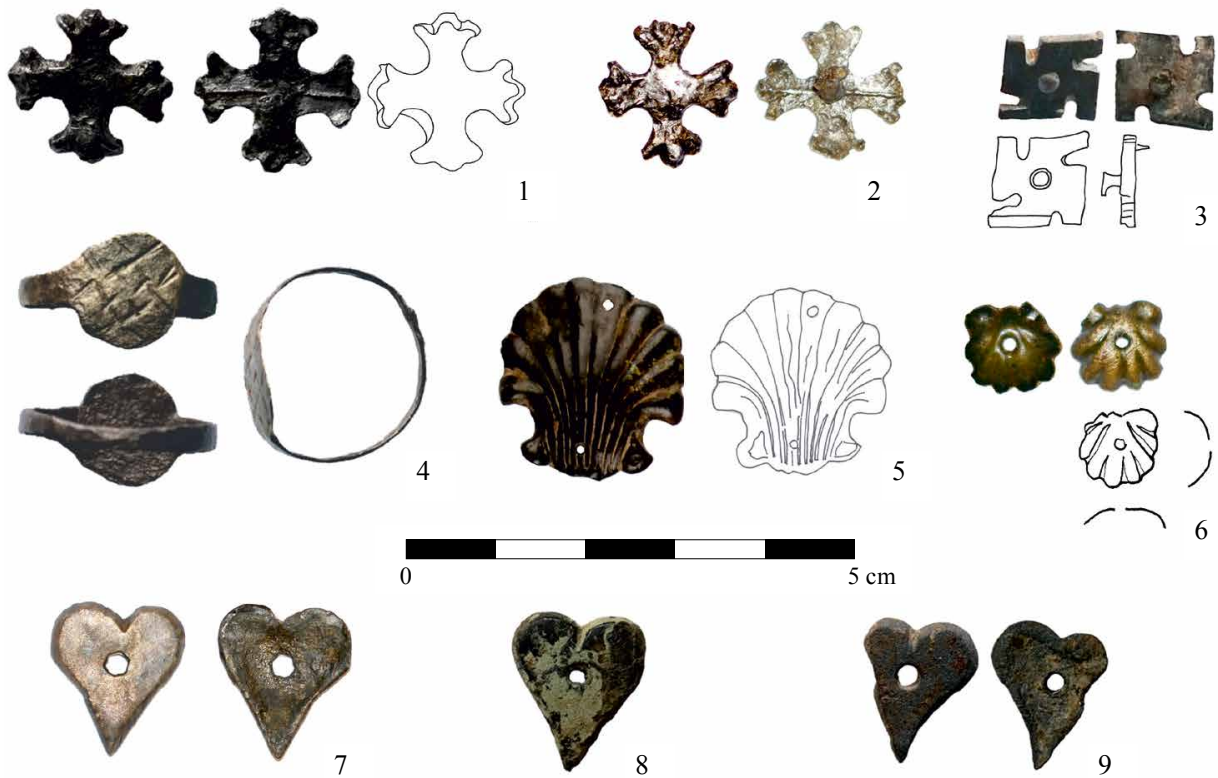

0

$5 \mathrm{~cm}$

7
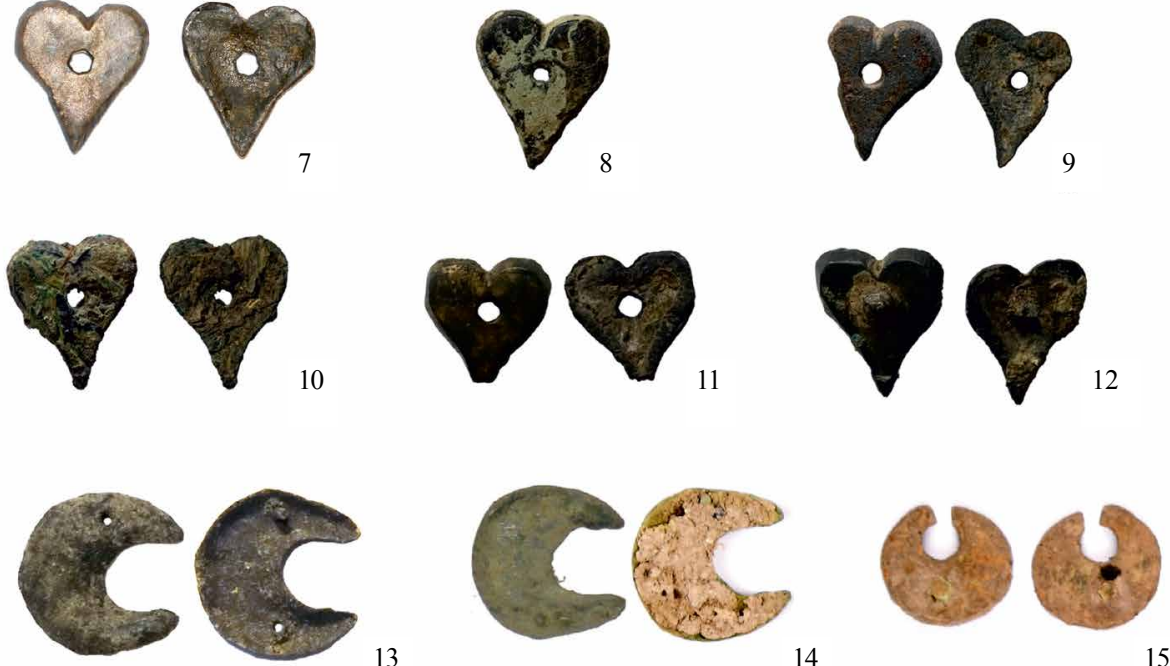

13

14

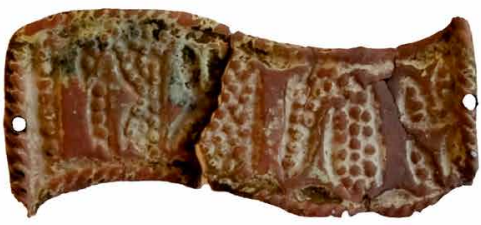

16

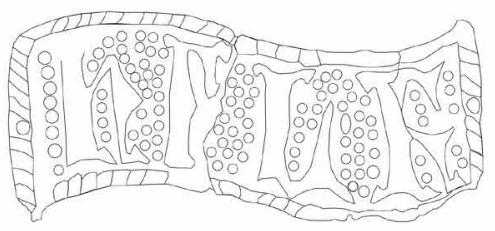

Fig. 3. Pustý hrad Castle in Zvolen. Small metal finds with religious motifs from the Upper Castle. 1-3 - motif of the cross; 4 - plate ring with a cross; 5 - pilgrim symbol - scallop shell; 6 - miniature scallop shell from the Lower Castle; 7-12 - heart motif; 13-14 - crescent motif; 15 - circular plate/crescent?; 16 - fitting with inscription $h I L F .1,4,8-12,15$ - trench 4/2020; 2 , 7 - trench 5/2016; 3 - trench 3/2017; 5 - trench 5/2019; 13 - 2/2017; 14, 16 - 1/2019. Photo J. Beljak; drawing N. Beljak Pažinová, S. Blahová.

Obr. 3. Pustý hrad vo Zvolene. Kovové miniatúry s náboženským motívom z Horného hradu. 1-3 - motív kríža; 4 - štítkový prsteň s motívom kríža; 5 - pútnický znak - mušl’a; 6 - drobná mušl'a z D olného hradu; 7-12 - motív srdca; 13-14 - motív polmesiaca; 15 - kruhový pliešok/polmesiac?; 16 - kovanie s nápisom $h I L F .1,4,8$-12, 15 - sonda 4/2020; 2, 7 - sonda 5/2016; 3 - sonda 3/2017; 5 - sonda 5/2019; 13 - 2/2017; 14, 16 - 1/2019. Foto J. Beljak; kresba N. Beljak Pažinová, S. Blahová. 
significance was multilayered, and, like the decorative elements, they also occurred in an explicitly mundane context (Šlancarová 2018, 221-237). Lily, which is still associated with purity and immaculateness of the body and soul, is part of the legend of the Annunciation. Rose is associated with love and as the queen of flowers, it pointed to the great spiritual importance of the Virgin Mary, who was the embodiment of love. The symbolism of the rose is used in Christianity in association with martyrs and the Innocents of Bethlehem (Royt-Šedinová 1998, 91).

Heraldic fleur-de-lis (lily flower) typically has three petals joined with a band in the middle. The side petals are smaller and outcurved. There are also blooming and half fleur-de-lis. In the domestic environment, the heraldic fleur-de-lis is strongly connected mainly with the Anjou dynasty from Naples that ruled Hungary at the beginning of the 14th century. Then, it became an inseparable part of symbols of states, towns (e. g. Brezno, Partizánska L'upča) and families. The origin of this symbol of royal power is, however, much older and goes back to the Merovingian kings. It was the symbol of France for centuries, until the fall of the monarchy. The staff terminated with the fleur-de-lis was also a typical attribute of the Hungarian kings from the Árpád period (Beaumont 1989; Bruna 2006; Ragač 2001; Takács 2012). The precisely executed silver fleur-de-lis (Fig. 4:1) depicted strictly after the rules of heraldry discovered in trench 3/2019 is the most representative example in the collection from the Upper Castle. The band in its centre has three jutting strips. Based on west European analogies, this fleur-de-lis might have been used to demonstrate the loyalty of its bearer to the newly established royal dynasty (Bruna 2006). Thus, together with majuscule $\mathrm{K}$, the monogram of Charles Robert of Anjou, it is a very good indicator for dating. The collection also includes two identical tiny specimens of decorative bronze rivets (?) in shapes of half fleurs-de-lis (Figs. 4:4, 5) discovered in trench 4/2020. The central petal is atrophied into a small triangular jut. The larger side petals are terminated with protruding small balls instead of tips. The bottom part of the fleur-de-lis is replaced by a protruding hemisphere. Another type of metal ornaments in the shape of the fleur-de-lis are known also from trenches $5 / 2017$ and 4/2020. They are fittings with the bottoms elongated into the shape of strips with loops at the end and their central petals end with circles on the tops (Figs. 4:2, 3). Two similar elongated fittings with loops without the side petals were also found in trench $3 / 2017$. However, they probably do not represent the fleur-de-lis (Figs. 4:6, 7).

The heraldic rose was depicted with five symmetrically arranged petals with small, pointed sepals between them from the Middle Ages onwards. The ovary in the middle is round and distinct (Rytír 1941). It is represented by the highest number of specimens in the collection (1 specimen in each of trenches 5/2016, 6/2018 and 3/2017; 2 specimens from trench 5/2019 and 6 specimens from trench 4/2020). All of them have six petals instead of the traditional five petals (Figs. 4:13-23). Apart from these changes, they follow the rules of precisely executed plastically designed fittings. In ten cases, the rose ovary has a shape of a protruding hemisphere. On two fittings, there are small perforations in sepals for attaching them to a base. Finally, there are five six-petal roses with pointed sepals (Figs. 4:8-12) resembling a star in the collection. Four of them were discovered in trench $4 / 2020$ and one is from trench 5/2020. Star is one of the oldest symbols of heaven and God, it bears light and shows the way to wanderers as well as lost and sinful souls (Royt-Šedinová 1998, 12, 13).

The crescent is another Marian symbol occurring among the finds of metal miniatures. The crescent is a symbol of purity, a symbol of Bethlehem and a symbol of fertility. The Moon is a celestial body associated with light visible in the evening, thus, it is an evening light and a symbol of power over the night (Novotný 1956, 417). The crescent is reliably represented in the assemblage by two almost identical individuals (Figs. 3:13, 14) with perforations for attaching them to a base. They were discovered in trenches $1 / 2019$ and $2 / 2017$. The most fragile specimens discovered in trench $4 / 2020$ is also the smallest one, with the most distinctly closed arms (Fig. 3:15). Nevertheless, in the case of this artefact, the question is whether it was a crescent or an additional perforation was made on an originally round artefact.

The heart is the last represented Marian symbol in the collection. In the Middle Ages, the heart as a symbol of love was strongly associated mainly with the secular environment. However, 

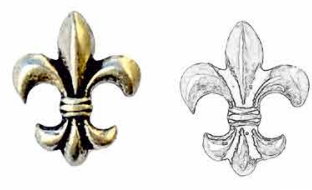

1
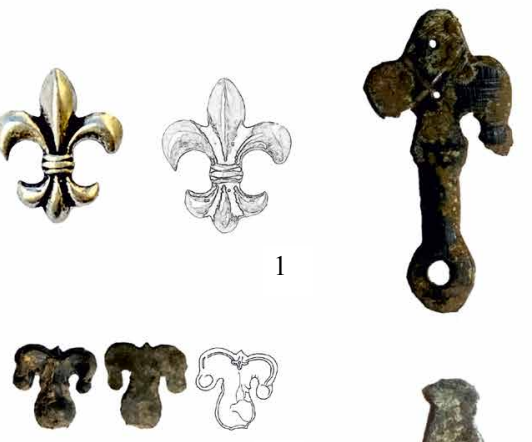

4

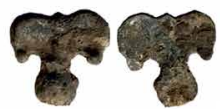

5
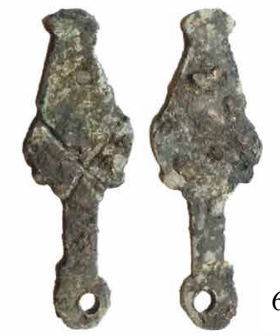

2
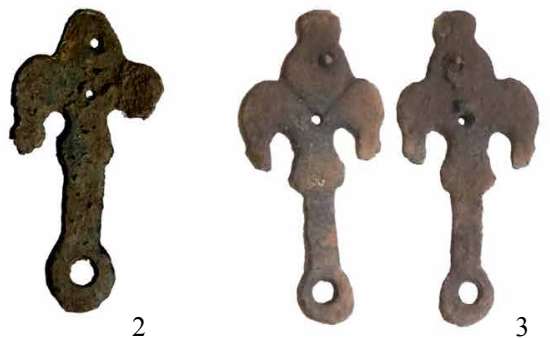

3

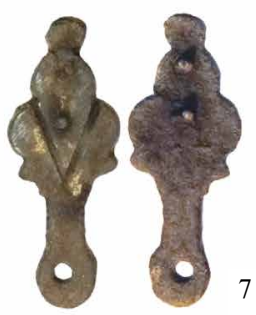

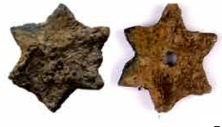

8
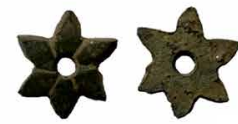

9

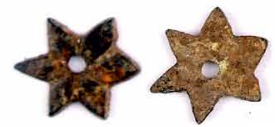

12

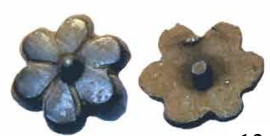

13
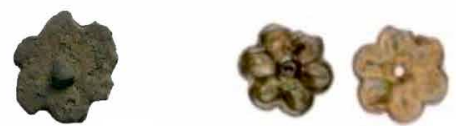

17

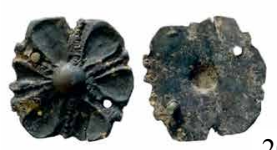

21

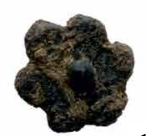

14

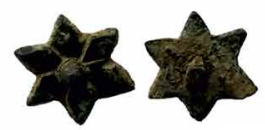

10

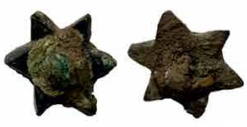

11
20

16

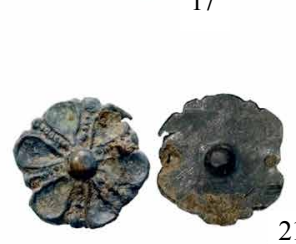

18

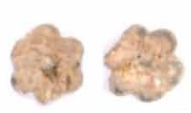

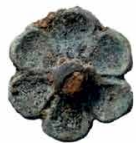

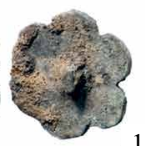

15

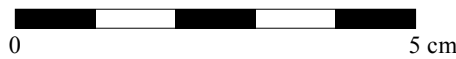

Fig. 4. Pustý hrad Castle in Zvolen. Small metal finds with religious motifs from the Upper Castle. 1-5 - motif of the fleurde-lis; 6-7 - metal ornament with a loop; 8-23-flower/rose motif. 1 - trench 3/2019; 2, 4, 5, 8-11, 14, 19-23-trench 4/2020; 3 - trench 5/2017; 6, 7 - trench 3/2017; 12 - trench 5/2020; 15 - trench 6/2018; 16 - trench 5/2016; 17, 18 - trench 5/2019. Photo J. Beljak; drawing N. Beljak Pažinová, S. Blahová.

Obr. 4. Pustý hrad vo Zvolene. Kovové miniatúry s náboženským motívom z Horného hradu. 1-5 - motív l’alie; 6-7 - kovová ozdoba s očkom; 8-23 - motív kvetu/ruže. 1 - sonda 3/2019; 2, 4, 5, 8-11, 14, 19-23 - sonda 4/2020; 3 - sonda 5/2017; 6, 7, 13 sonda 3/2017; 12 - sonda 5/2020; 15 - sonda 6/2018; 16 - sonda 5/2016; 17, 18 - sonda 5/2019. Foto J. Beljak; kresba N. Beljak Pažinová, S. Blahová. 
it also had undisputable spiritual significance (Šlancarová 2018, 221-237). In the court environment, its symbolical meaning was associated with the expression of the cultivated unrequited courtly love of a knight for a lady from the 12 th century. The heart has been a traditional heraldic figure since the Middle Ages as well. It was usually used to fill the shield area. Its symbolism in various forms is also traditionally part of the burgher culture and folklore. As for archaeological finds, we know e. g. its variants with roses, still used hearts pierced with arrows, or crowned hearts (Bruna 2006). In the collection from the Upper Castle there are six specimens of identical stylized flat hearts (Figs. 3:7-12) from trenches 5/2016 (1 specimen) and 4/2020 (5 specimens). With one exception, they have round perforations in their centres, probably for attaching or sewing them to a base.

\section{Attributes of saints}

Attributes of saints are represented in the collection only by a single identified piece. It is a scallop shell, a traditional attribute of St. James the Greater. In the Middle Ages, this symbol was strongly connected with pilgrimages to the city of Santiago de Compostela in northern Spain (Galicia), the most important medieval pilgrimage centre in Europe (Ashley-Deegan 2009). The local ancient pilgrimage tradition has its roots in the 10th century. Numerous pilgrims from the whole of Europe traditionally decorated their clothes, hats, satchels, and other equipment with St. James shells (Roux 1999; Bruna 2006). It acted as a practical symbol for pilgrims - identifying them and thereby giving them some protection and support from locals and fellow travellers. The bronze scallop mount (size approx. $2 \times 2 \mathrm{~cm}$ ) was produced very precisely, with many miniature details and two holes for sewing on hat or clothes (Fig. 3:5). The find was discovered on the hilltop plateau in trench 5/2019. A smaller specimen with one central hole was discovered almost then years ago at the Lower Castle (Fig. 3:6; Beljak et al. 2014, 201, Fig. 157:5), but the one from the Upper Castle is way bigger and better executed.

Their possible decorative purpose, known from foreign analogies, cannot be completely excluded either (Spencer 2010, cat. nos. 250 and 250c). In domestic art, the scallop shell in a mundane context, with exceptions, only appeared later.

\section{Discussion}

The presented assemblage of small metal finds points to the presence of belief in everyday life of the inhabitants at Pustý hrad Castle in Zvolen. The collection consists of appliqués made of non-ferrous metals and used as ornaments, small patches, belt mounts, fittings, badges, and dress pendants. They were personal goods that also communicated a certain message. They could be presented or worn on certain occasions and most likely, the purpose and symbolism of these items differed depending on their owner. For the believers, they were an important part of their belief, could be used at personal prayers, had a protective function, and were associated with their bearers' view of the world. In the European context, we find a wide range of motifs on small medieval metal finds (Krabath 2001; Sawicki 2014; 2017). Various forms of stylizations and symbolical expressions connected them not only to religion but also to secular medieval life. The collected and evaluated assemblage from the Upper Castle is thus an important insight into the life of its inhabitants and presents the material culture of the castle environment.

The spiritual belief - by means of the depicted symbols - from the presented collection is clearly represented by pilgrim souvenirs and badges (Haasis-Berner 2003; Čechura 2009, 554-555; Velimský 1998; 2006; Spencer 2010). Only one St. James scallop mount was found in the processed assemblage (Fig. 3:5). However, it is an important confirmation that there was at least one person at the castle who completed a pilgrimage to Santiago de Compostela.

The frequency of the occurrence of this type of source at Pustý hrad Castle is unique, as we find mostly individual items or smaller collections from one site (e. g. Bielich 2015, 127, Fig. 12:7; 
Drnovský 2018, 150-186; Krauskopf 2005, 91-96, 216-227; Marciniak-Kajzer 2011, 226-237; Tymonová 2010, 70, Fig. 4; Vích 2019, 50, 54-55). The collected and evaluated assemblage from the Upper Castle is thus an important insight into the life of its inhabitants and presents the material culture of the castle environment.

Evaluation of the collection of small metal finds has brought important information also from the perspective of the find context and the dating of finds. The source base consisting of 34 artefacts came from the site of the Upper Castle and it was found during the research seasons of 2016-2020. ${ }^{1} 28$ archaeological trenches (with a total area of $1,378 \mathrm{~m}^{2}$ ) were excavated during these five seasons. Small metal finds with religious motifs were discovered in 10 of them (Fig. 2). Sporadic finds found near the entrance gate of the Upper Castle along the southern line of the curtain wall are considered common abandoned or lost artefacts (Figs. 3:13, 16) as well as on the lower terrace outside the Donč castle area (Fig. 4:3) and on the courtyard in front of the entrance to the palace of the Donč castle (Fig. 4:15). The area of the Upper Castle hilltop plateau (Fig. 5) is a different case. As early as season 2016, it was possible to state that the richest source fund (almost $90 \%$ of the discovered finds) comes from this area near the flanking tower in the eastern line of the curtain wall. Thus, the excavations there continued systematically also in 2019 and

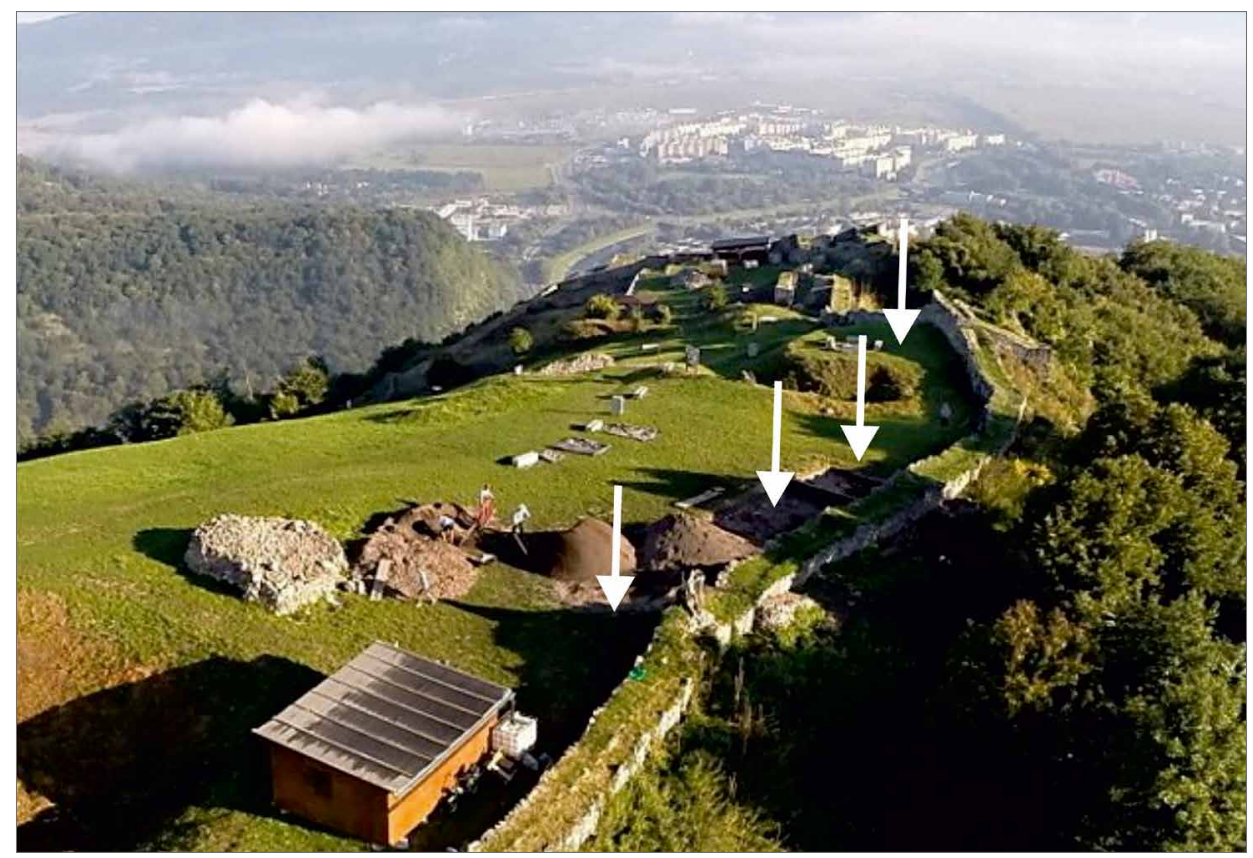

Fig. 5. Pustý hrad Castle in Zvolen. Aerial view from the south of the hilltop plateau of the Upper Castle near the flanking tower in the eastern line of the curtain wall. Arrows indicate the area with the highest concentration of archaeological finds. Photo J. Beljak.

Obr. 5. Pustý hrad vo Zvolene. Letecký pohl’ad z juhu na vrcholovú plošinu Horného hradu v blízkosti veže vo východnej línii opevnenia. Š́pkami značený areál s najväčšou koncentráciou archeologických nálezov. Foto J. Beljak.

1 Finds from the previous years of excavations at the Upper Castle (seasons 1992-2008) when they were led by V. Hanuliak were not included in this study for two reasons: 1) in the pandemic period of 2020-2021, depositories of museums are closed and it is currently not possible to work with older collections; 2) the aim of the article is to call the attention to the concentration of finds mainly from the hillfort plateau of the Upper Castle, where V. Hanuliak carried out only a little work from the aspect of areal excavation. Therefore, the number of finds he discovered in this area is not essential for the objective of our study. 
2020 and allowed the accumulation of an extraordinarily rich collection of (not only) ${ }^{2}$ medieval finds from the 13th-1st half of the 14th century. ${ }^{3}$ Twenty eight artefacts associated with small metal finds were found in this area, which cannot be a coincidence and they cannot be common abandoned artefacts occurring in other castle areas either. Stratigraphy in trenches 5/2016, 3/2017, $3 / 2019$ and 4/2019 points to the destruction horizon under which a massive layer complex (Fig. 6) is located and can relate to the settlement activity during the castle's operation in the High Middle Ages. Remains of stone tiles, mortar floors and other structures confirming the existence of buildings with wooden construction attached to the inner face of the Upper Castle's eastern curtain wall were confirmed in the trenches.

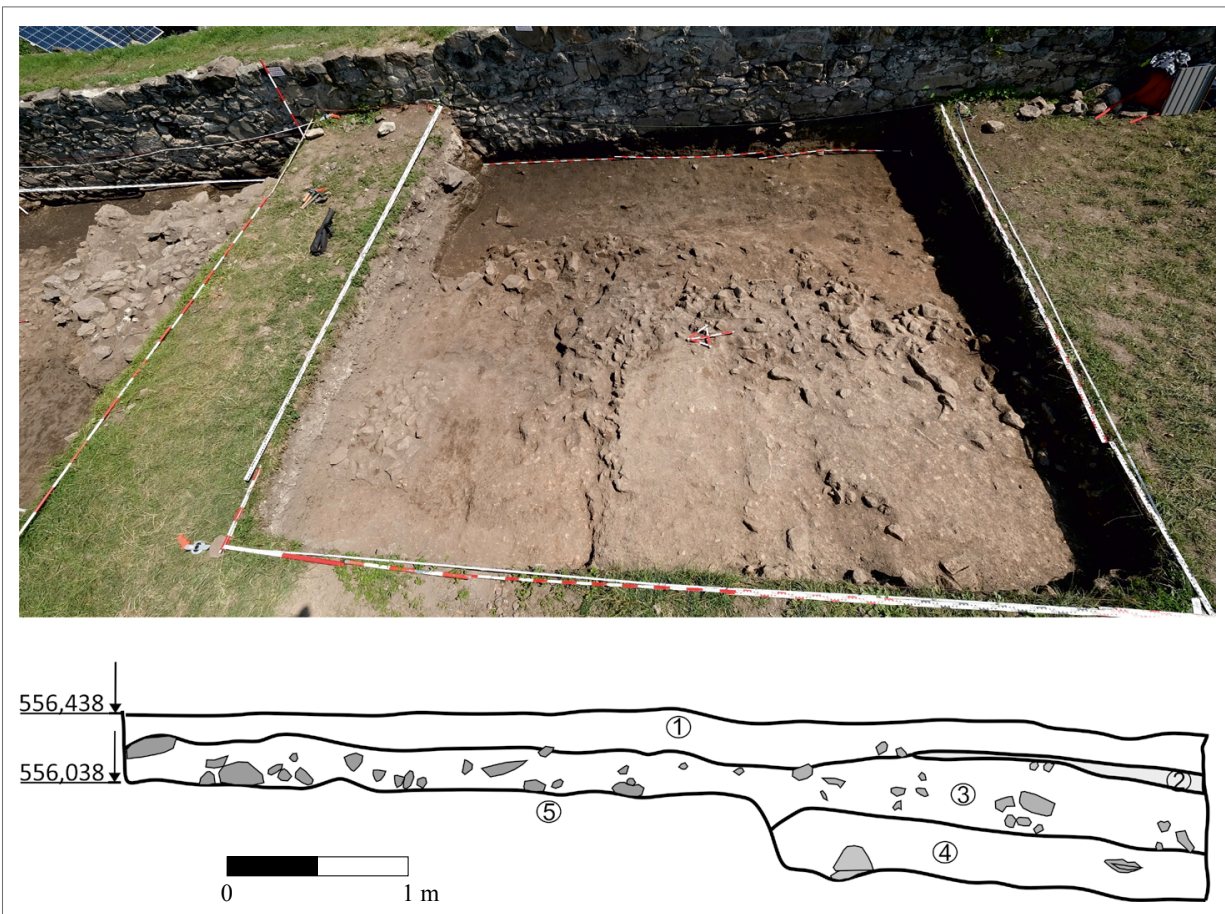

Fig. 6. Pustý hrad Castle in Zvolen. Top - view of the studied interior of the southern part of trench 4/2020: artificially levelled andesite rock for construction of log houses in the foreground. Photo J. Beljak. Bottom - western profile with the cultural layer complex: 1 - pale brown loam-stone layer (overburden), 2 - brown mortar-sand layer, 3 - dark brown loam (cultural) layer from the High Middle Ages with stones, 4 - mixed brown-grey loam (cultural) layer from the High Middle Ages and the Late Bronze Age, 5 - trimmed/levelled andesite rock. Drawing N. Beljak Pažinová.

Obr. 6. Pustý hrad vo Zvolene. Hore - pohl’ad na preskúmaný interiér južnej časti sondy 4/2020: v popredí umelo zarovnané andezitové bralo na výstavbu zrubových obydlí. Foto J. Beljak. Dole - západný profil s kultúrnym súvrstvým: 1 - svetlohnedá hlinito-kamenná vrstva (nadložie), 2 - hnedá maltovo-piesková vrstva, 3 - tmavohnedá hlinitá (kultúrna) vrstva z vrcholného stredoveku s kameňmi, 4 - premiešaná hnedočierna hlinitá (kultúrna) vrstva z vrcholného stredoveku a neskorej doby bronzovej, 5 - upravené/zarovnané andezitové bralo. Kresba N. Beljak Pažinová.

2 A rich prehistoric layer has been recorded in the same area corresponding with the Late and Final Bronze Age, i. e. the period when a hillfort of the Lusatian, and later of the Kyjatice culture was built at the site (for more information see Beljak-Beljak Pažinová-Putško, in press; Beljak-Putško-Beljak Pažinová, in press).

3 These statements are confirmed by 14C AMS dating carried out by the Radiocarbon Laboratory in Poznań in 2021 from samples of animal bones or bone artefacts. Calibration of the obtained data was edited in OxCal v. 4.2.2. software. Sample 1 (bone plate) from trench $5 / 2019$ : 1216-1265 AD (68.3\%) and 1175-1273 AD (95.4\%); sample 2 (animal bone) from the interior of the flanking tower in the eastern line of the curtain wall: $1278-1301$ AD (57.6 \%); 1270-1316 AD (69.4\%); 1360-1388 AD (26.1\%). 
The interior of the flanking tower in the eastern line of fortification was searched by trench $5 / 2020$. Nevertheless, it was a mixed, not a primary, depot, since the fill of the tower was previously disturbed by V. Hanuliak (1999, 353-354) in 1996-1998. Despite this, it was possible to document (with careful sieving and use of a metal detector) numerous finds including one metal miniature with a motif of a rose with pointed petals (Fig. 4:12).

Trenches 2/2017 and 5/2019 were in places allowing to document mainly the ditch in the courtyard in front of the flanking tower in the eastern line of the curtain wall. Four artefacts from the miniatures were found there: a St. James scallop mount (Fig. 3:5), the motif of the crescent (Fig. 3:13) and the rose motif (Figs. 4:17, 18). The discovered finds are mostly deposited waste from the seat or the period after the ditch had been actively used. The building of a separated ditch for the flanking tower in the eastern line of the curtain wall was dated by V. Hanuliak $(2006,262)$ to the mid-15th century and associated with Jan Jiskra's stay in Zvolen. Nevertheless, this fact was not proven by our excavation; just the opposite, the find context as well as the individual finds (not only small metal artefacts) suggest the end of the ditch in the mid-14th century at the latest. It means that it was built earlier, and it can be associated with the events in the period of the death of the Hungarian kings from the Árpád dynasty when the administrators of the Zvolen County took power over the castle and turbulent times began (Kristó 1973). In 1306, King Charles Robert conquered the castle of Zvolen (Pustý hrad) as well as Slovenská Lupča, Dobrá Niva and Plachtince (for more information see Hanuliak 1999, 353). The situation at the castle became stable probably with the royal reform of Charles Robert. The role of the castle changed as well - instead of the Zvolen County, only a smaller territorial unit - the area of the Noble County of Zvolen (for more information see Beljak et al. 2014, 44) was subject to it. The old royal castle on the top of the hill above the town of Zvolen gradually lost its residential function, which is confirmed by the building of a modern Gothic castle - the Castle of Zvolen near the town by Louis, son of Charles Robert (1342-1382) (Beljak-Beljak Pažinová-Šimkovic 2018, 21, Fig. 26). Our results support this fact since we do not find any significant proof of continuous residence in the second half of the 14th century at Pustý hrad Castle. The 15th century is very rare in the excavated assemblages. Pustý hrad Castle lost its previous importance and fortification function in the late 14th century, which corresponds to the fact that the old seat of the Zvolen County's administrators and kings gained the name of the Old Castle at the end of the Middle Ages (Beljak-Beljak Pažinová-Šimkovic 2018, 22).

In conclusion, we must not forget the existence of the considerably rich cultural layer from the 13th - mid-14th century at the hilltop plateau around the central part of the Upper Castle near the flanking tower (Fig. 5). Eighty eight percent of the discovered artefacts were found there. Such concentration is not a result of common waste, it is a purposeful activity that might be associated with an intense craft activity. V. Hanuliak (1999; 2001, 188, 190) assumed the existence of general workshops at the castle in the past. He located one of them at the above-mentioned parts of the hilltop plateau or exactly in the flanking tower. In the social environment of an important royal seat, which Zvolen Castle was in the 13th and 14th centuries, we can expect a specialized workshop (workshops) dealing with purposeful production of various products. In the previous years, we recorded a high number of metal plates ready for minting and coin discs in the hilltop plateau (Beljak-Beljak Pažinová 2018, 215). In association with counterfeit Hungarian denarii and Wiener pfennigs regularly occurring at the castle (Hanuliak-Hunka 2000, 364, 365) as well as discovered clay crucibles with traces of precious metals (Beljak-Beljak Pažinová-Šimkovic 2018, 46, 48), it is highly probable that in this very area, the craft focused on metal casting and needless artefacts made of precious metals were molten and used to produce silver-copper coin plates. These were cut into smaller circular, oval and square coin discs and counterfeit minting was applied to them later (Oslanský 1998). Similar activities are not uncommon and are documented from other castles and feudal seats from the territory of Slovakia as well (Slivka 1992; Soják 2013). The concentration of small metal finds are therefore considered possible evidence of a functioning workshop for money 
forging activities right at the Upper Castle in the High Middle Ages. Such activity must have taken place under the "supervision" of a powerful noble despite the laws punishing counterfeiting coins by property loss which were issued by Andrew III in 1298. The beginning of the 14th century, i. e. the turbulent times after the Árpád dynasty demise when certain activities could have been ignored or it was hard to track them down and control them, was particularly convenient for making fake coins at the castle (Hunka 2013, 107-110).

\section{Conclusion}

The small metal finds with religious motifs described in the article are a unique phenomenon within the evaluation of collections of medieval metal items from Pustý hrad Castle in Zvolen, except for the previously evaluated heraldic motifs on small metal finds from the same site (Ragač 2001). We aimed to present and analyse 34 artefacts from seasons 2016-2020 and consider their role or importance in the material culture discovered in the high medieval royal castle. The presented minor metal appliqués (fittings, badges, mounts and patches of various shapes, fasteners) belonged mainly to personal goods suggesting a high social status of their owners. They also reflected their spiritual beliefs and - by means of the depicted symbols - brought peace, protection, and possibly also conveyed a message. The decorative and other functions that also linked them to secular medieval life should not be omitted, either. It is obvious that many motifs have various meanings in everyday life. This may indicate that the people needed to be surrounded by certain images that functioned in their culture. A question arises, what did this symbol mean to a specific medieval recipient? It cannot be ruled out that they could be presented or worn on certain occasions and most likely, the purpose and symbolism of these items differed depending on their owner.

In the form of discussion, the article also deals with the distinct concentration of this type of source at the Upper Castle, specifically in the area of the hilltop plateau near the flanking tower in the eastern line of the curtain wall. We also dealt with their possible role in crafts and coin counterfeiting. We pointed out the fact that their above-average occurrence in one place cannot be coincidental and, thus, we do not consider them common abandoned or lost artefacts. Just the opposite, the density of their occurrence in the context with other finds and cultural layers documents an active production on the site associated with metallurgy. This activity is dated to the turn of the 13th and 14th centuries, based on the uncovered contexts.

In conclusion, we can state that the systematic excavations at the Upper Pustý hrad Castle in Zvolen, which have been continuing since 2015 after a break lasting for several years, have brought a more detailed identification of construction stages of the royal seat during the 13th-mid14 th century as well as better interpretation of life and activities of the inhabitants. It is even more motivating for us to continue and bring further information about life of the royal seat itself.

This work was supported by the Slovak Research and Development Agency under contract No. APVV-17-0063.

\section{Bibliography}

ASHLEY, K.-DEEGAN, M., 2009: Being a Pilgrim: Art and Ritual on the Medieval Routes to Santiago. Burlington, $\mathrm{Vt}$.

BARAČKOVÁ, L., 2014: Experimentální výroba středověkých šperků z archeologického naleziště Lumbeho zahrada na Pražském hradě. In: Pohřebiště v Lumbeho zahradě na Pražském hradě (Frolík, J., ed.), 311-418. Praha.

BEAUMONT, A., 1989: Recherches sur l' origine du blason et en particulier sur la fleur de lis. Paris.

BELJAK, J., et al., 2014: Pustý hrad vo Zvolene, Dolný hrad 2009-2014. Nitra.

BELJAK, J.-BELJAK PAŽINOVÁ, N., 2016: Tajomstvo stredovekej cisterny, Quark: magazín o vede a technike 22 , č. $3,7-11$. 
- 2018: Výskum a obnova Pustého hradu vo Zvolene - Research and renovation of the Pustý hrad (Deserted castle) in Zvolen. In: Stredné Slovensko v stredoveku: vývoj osídlenia regiónu pred udelením mestských privilégií mestu Zvolen (Beljak Pažinová, N.-Borzová, Z., edd.), 212-235. Zvolen.

- 2020: Benefits of the long-term research into the Pustý hrad castle (Deserted castle) in Zvolen and its prospects for the future - Prínos dlhodobého výskumu lokality Pustý hrad vo Zvolene pre bádanie a jeho perspektíva do budúcnosti, AH 45, č. 2, 941-956. https://doi.org/10.5817/AH2020-2-20

BELJAK, J.-BELJAK PAŽINOVÁ, N.-KVIETOK, M., 2015: Výskum na Pustom hrade vo Zvolene, AVANS v roku 2010, 47-51.

BELJAK, J.-BELJAK PAŽINOVÁ, N.-PUTŠKO, M., in press: Nové výsledky výskumov výšinnej osady badenskej kultúry a opevneného hradiska z neskorej doby bronzovej na Pustom hrade vo Zvolene (Slovensko) - New excavation results of the Baden culture uphill settlement and fortified hill-fort from the Late Bronze Age in Pustý hrad castle in Zvolen (Slovakia). In: Pod stromom života. Zborník k 70. narodeninám Michala Slivku (Bača, M., ed.), 11-30. Bratislava.

BELJAK, J.-BELJAK PAŽINOVÁ, N.-ŠIMKOVIC, M., 2016: Nálezy z cisterny na Pustom hrade vo Zvolene, Pamiatky a múzeá: revue pre kultúrne dedičstvo 65, č. 3, 7-12.

- 2018: Pustý hrad vo Zvolene a hrad Pet'uša vo svetle aktuálnych výskumov. Zvolen.

BELJAK, J.-PUTŠKO, M.-BELJAK PAŽINOVÁ, N., in press: Unusual find of newborn skeletal remains from the Late Bronze Age settlement at Pustý hrad (Deserted castle) in Zvolen (Central Slovakia). Zborník z konferencie Epoka brazu i wczesna epoka zelaza w Karpatach (The Bronze Age and the Early Iron Age in the Carpathian Mountains).

BELJAK PAŽINOVÁ, N.-BELJAK, J., 2016: A zólyomi Pusztavár ciszternájának 2015. évi ásatása, Castrum - A Castrum Bene Egyesület folyóirata 19, 105-110.

BIELICH, M., 2015: Archeologický výskum Lietavského hradu v rokoch 2012-2013: piata a šiesta výskumná sezóna - Archaeological research into Lietava Castle in 2012-2013: research seasons five and six, AH 40, 115-129. https://doi.org/10.5817/AH2015-1-7

BRUNA, D., 2006: Enseignes de plomb et autres menues chosettes du Moyen Âge. Paris.

ČECHURA, M., 2009: Církevní hmotná kultura v archeologických pramenech - Die kirchliche Sachkultur in archäologischen Quellen, AH 34, 543-561.

ČIERNY, M.-BELJAK PAŽINOVÁ, N.-BELJAK, J., 2020: Zdobená kostená rukovät' z Pustého hradu vo Zvolene - Decorated bone handle from Pustý hrad (Deserted Castle) in Zvolen, ŠZ AÚ SAV 67, 371-381. https://doi.org/10.31577/szausav.2020.67.17

DRNOVSKÝ, P., 2018: Hmotná kultúra šlechtických sídel severovýchodních Čech. Každodennost’ středověku pohledem archeologie. Hradec Králové.

GROSS, L., 1999: Clerical Fraternities in Medieval Transsylvania. In: Church and Society in Central and Eastern Europe (Crăciun, M.-Ghitta, O., edd.), 22 -34. Cluj - Napoca.

HAASIS-BERNER, A., 2003: Pilgerzeichen des Hochmittelalters (Veröffentlichungen zur Volkskunde und Kulturgeschichte 94). Würzburg.

HANULIAK, V., 1993: Historicko-archeologický výskum Pustého hradu vo Zvolene - Historisch-archäologische Forschung in Zvolen, AH 18, 161-166.

- 1999: Doklady hmotnej kultúry zo Starého Zvolena (Pustého hradu) od 12. do 17. storočia - Materielle Kultur aus Alt-Zvolen (Pustý hrad, dt.: „Wüste Burg“) im 12.-17. Jahrhundert, AH 24, 352-361.

- 2001: Materiálne doklady remeselníckych dielní na Pustom hrade - Sachliche Belege der handwerklichen Werkstätte in der „Pustý hrad“ - Wüsten Burg, AH 26, 185-191.

- 2006: Vojenské pevnosti Jána Jiskru vo Zvolene - Militärische Festung des hussitischen Feldherrn Jan Jiskra in Zvolen, AH 31, 259-268.

HOFER, N., Hrsg., 2014: Der Schatzfund von Wiener Neustadt. Wiener Neustadt.

HUNKA, J., 2013: Mince Arpádovcov z rokov 1000-1301. Ich podiel na vývoji hospodárstva stredovekého Slovenska. Nitra.

HUNKA, J.-BELJAK PAŽINOVÁ, N.-BELJAK, J., 2021: Hlinená forma na odlievanie falošných mincí z Pustého hradu vo Zvolene, Studia Historica Nitriensia 25, 427-455. 
KRAUSKOPF, Ch., 2005: Tric-Trac, Trense, Treichel. Untersuchungen zur Sachkultur des Adels im 13. und 14. Jahrhundert. Braubach.

KUBINYI, A., 1999: Főpapok, egyházi intézmények és vallásosság a középkori Magyarországon. Budapest.

KRABATH, S., 2001: Die hoch- und spätmittelalterlichen Buntmetallfunde nördlich der Alpen. Eine archäologisch-kunsthistorische Untersuchung zu ihrer Herstellungstechnik, funktionalen und zeitlichen Bestimmung. Rahden/Westfallen.

KRISTÓ, G., 1973: Magister Donč a Matúš Čák Trenčiansky, Historické štúdie 18, 235-245.

MARCINIAK-KAJZER, A., 2011: Średniowieczny dwór rycerski w Polsce. Wizerunek archeologiczny. Łódź.

NODL, M.-ŠMAHEL, F., edd., 2014: Slavnosti, ceremonie a rituály v pozdním středověku. Praha.

NOVOTNÝ, A., 1956: Biblický slovník. Praha.

OSLANSKÝ, F., 1998: Z písomných prameňov o falšovaní mincí v stredoveku, Slovenská numizmatika 15, 77-88.

PÄTZOLD, K.-WEISSBECKER, M., edd., 2006: Schlagwörter und Schlachtrufe aus zwei Jahrhunderten deutscher Geschichte. Digitale Bibliothek. Band 143. Berlin.

PROKISCH, B.-KÜHTREIBER, Th., Hrsg., 2004: Der Schatzfund von Fuchsenhof. Linz.

RAGAČ, R., 2001: Heraldické motívy na kovovej miniatúre z lokality Zvolen-Pustý hrad - Heraldische Motive auf der metallenen Miniatur aus der Lokalität Zvolen-Pustý hrad, AH 26, 441-445.

RAPP, F., 1996: Církev a náboženský život Západu na sklonku středověku. Praha.

ROUX, J., 1999: Les Chemins de Saint-Jacques de Compostelle. Paris.

ROYT, J.-ŠEDINOVÁ, H., 1998: Slovník symbolů: kosmos, prŕíroda a člověk v křest’anské ikonografii. Praha. RULÍŠEK, H., 2005: Postavy, atributy, symboly. Slovník křest’anské ikonografie. Hluboká nad Vltavou.

RYTÍŘ, V., 1941: Heraldická růže. Soupis sídelních městských znaků s obrazem růže. Úvaly.

SAWICKI, J., 2014: Średniowieczne Świeckie odznaki w Polsce na tle Europejskim - Medieval secular badges in Poland against the European background. Wrocław.

- 2017: Medieval dress accessories from Nowy Targ Square in Wrocław Catalogue of finds. Wrocław.

- 2018: Organization of production and trade of minor metal items at Nowy Targ (New Market) Square in medieval Wroclaw in the light of the production waste - K organizaci výroby a prodeje drobných kovových předmětů na náměstí Nowy Targ ve středověké Vratislavi podle analýzy výrobního odpadu, AR LXX, 110-134.

SLIVKA, M., 1992: Falšovanie mincí na slovenských hradoch, Slovenská numizmatika 12, 53-66.

- 2017: Inskripcie v stredovekom archeologickom materiáli z územia Slovenska I. - Inscriptions among medieval archaeological material from Slovak territory I., AH 42, 819-847. https://doi.org/10.5817/AH2017-2-20

ŠLANCAROVÁ, V., 2018: Středověký šperk. Archeologické nálezy z jižní Moravy. Brno. https://doi.org/10.5817/ CZ.MUNI.M210-9021-2018

SOJÁK, M., 2013: Falšovanie mincí v stredoveku a novoveku v oblasti východného Slovenska (stručný prehl'ad stavu bádania za poslední desat'ročie). In: Baníctvo a mincovníctvo v dejinách Slovenska (Haas Kianička, D., ed.), 37-52. Kremnica.

SPENCER, B., 2010: Pilgrim Souvenirs and Secular Badges. Medieval Finds from Excavations in London. Woodbridge.

ŠEDIVÝ, J., 2019: Beiträge zur mittelalterlichen deutschspachigen Schriftkultur in der Slowakei I. Bratislava. TAKÁCS, I., 2012: Az Árpád-Házi királyok pecsétjei - Royal Seals of the Árpád Dynasty. Budapest.

TYMONOVÁ, M., 2010: Archeologické doklady každodenního života obyvatel hradu Cvilína v období středověku a raného novověku - Archäologische Belege des Alltagslebens der Bewohner von Burg Cvilín in der Zeit des Mittelalters und der frühen Neuzeit, AH 35, 63-79.

VELÍMSKÝ, T., 1998: K nálezům středověkých poutních odznaků v českých zemích - Zu den Funden der mittelalterlichen Pilgerzeichen aus den böhmischen Ländern, AH 23, 435-455.

- 2006: Sv. Anna, ochránkyně středověkých manželství. Z pohledu jednoho drobného archeologického nálezu - Die heilige Anna, Beschützerin der mittelalterlichen Ehe. Aus der Sicht eines kleinen archäologischen Fundes. In: Ve znamení zemí Koruny české, 452-462. Praha.

VÍCH, D., 2019: Hrad Zítkov u Chocně ve světle archeologických nálezů - Die Burg Zítkov bei Choceň im Lichte der archäologischen Funde, AH 44, 29-63. https://oi.org/10.5817/AH2019-1-2 


\section{Zhrnutie}

\section{Prejavy viery na Pustom hrade vo Zvolene vo svetle nálezov kovových miniatúr}

V príspevku je spracovaný súbor stredovekej kovovej miniatúry (13. až 14. storočie) z Pustého hradu vo Zvolene (obr. 1). Vybrané boli také tvary, ktoré reprezentujú (nielen) náboženskú symboliku, ktorej sa na Slovensku venuje len ojedinele (Slivka 2017). Heraldické motívy na kovovej miniatúre z rovnakej lokality už boli spracované (Ragač 2001). Analyzované artefakty v celkovom počte tridsat' štyri kusov boli objavené v rámci výskumných sezón 2016 až 2020 na Hornom hrade a pochádzali z nasledovných plôch (obr. 2):

- z blízkosti vstupnej brány Horného hradu pri južnej línii opevnenia - sonda 1/2019: dva predmety ( $\mathrm{z}$ toho 1 kovanie s nápisom pozostávajúce $\mathrm{z} 2$ fragmentov);

- z vrcholovej plošiny v blízkosti veže vo východnej línii opevnenia - sonda 5/2016;2/2017; 3/2017; 3/2019; 5/2019; 4/2020; 5/2020: tridsat' predmetov;

- z dolnej terasy predhradia, tzv. Dončovho hradu - sonda 5/2017: jeden predmet;

- z nádvoria pred vstupom do paláca, tzv. Dončovho hradu - sonda 6/2018: jeden predmet.

Druhové triedenia náboženských motívov na kovovej miniatúre z Horného Pustého hradu bolo nasledovné:

- základný krest’anský symbol - kríž reprezentujú tri predmety (obr. 3:1-3);

- atribút svätca je zastúpený jediným exemplárom - mušl’a hrebenatka (obr. 3:5);

- mariánske motívy mali najväčšie zastúpenie (obr. 3:7-14; 4:1-5; 8-23): dominoval symbol ruže (16 ks), menej bola zastúpená l'alia (5 ks), srdce (6 ks) a polmesiac $(2 \mathrm{ks})$. Mariánsky symbol bol prítomný aj prostredníctvom kovania s nápisom (obr. 3:16).

Predstavené kovové nálezy (nášivky rôznych tvarov, spínadlá) patrili hlavne medzi predmety osobnej výbavy poukazujúce na vyššie sociálne postavenie ich majitel’ov. Kovové miniatúry súviseli s vnímaním sveta ich nositel’ov, pre veriacich boli dôležitou súčastou ich presvedčenia, mohli slúžit' pri osobných modlitbách a mali azda i ochrannú funkciu. Viacvýznamovost' jednotlivých miniatúr ich samozrejme prepájala aj so svetským životom stredovekého človeka.

$\mathrm{Z}$ analyzovaných predmetov vyzdvihnút' treba svätojakubskú mušl'u (obr. 3:5) s otvormi na našitie na klobúk, prípadne odev, ktorý je dôležitým dokladom, že na hrade vo vrcholnom stredoveku bol aspoň jeden človek, ktorý uskutočnil cestu do Santiaga de Compostella (Ashley-Deegan 2009). Výnimočné je aj subtílne kovanie v tvare zvlnenej olemovanej nápisovej pásky s dvomi drobnými otvormi umiestnenými v stredoch lemu jej kratších strán (obr. 3:16). Na jeho puncovanej ploche je krátky nemecký nápis „hILF“. Použitie minuskuly (prvá litera) v kombinácii s majuskulou podčiarkuje archaickost' nápisu, ktorý vznikol v prvých desat'ročiach 14. storočia. Bojové heslo „Maria hilf“ sa rozšírilo počas križiackych výprav v druhej polovici 13. storočia a je spojené aj s francúzskym král'om L’udovítom IX. Svätým (Pätzold-Weissbecker 2006). Tento nález je unikátny aj z pohl'adu domácej stredovekej písomnej kultúry, pričom ide o najstarší známy nemecký nápis z územia Slovenska. S d’alšími nemeckými epigrafickými pamiatkami sa v domácom prostredí stretávame až na začiatku 15. storočia (Šedivý 2019).

$\mathrm{V}$ príspevku sme sa formou diskusie zamysleli aj nad výraznou koncentráciou tohto druhu prameňa na Hornom hrade, resp. v priestore vrcholovej plošiny pri veži vo východnej 
línii opevnenia Pustého hradu (obr. 5; 6) a o jeho možnej úlohe pri remeselnej a peňazokazeckej činnosti. Poukázali sme na to, že ich nadmerný výskyt na jednom mieste nemôže byt' náhodný, a preto ich nepokladáme za bežné stratové predmety. Práve naopak, ich hustota výskytu v kontexte s d’alšími nálezmi a terénnymi situáciami vypovedá o aktívnej výrobnej činnosti na danom mieste spojenej s tavbou kovov na prelome 13./14. storočia. Táto aktivita mohla súvisiet's razbou falošných mincí, ktorých doklady na hrade pravidelne nachádzame (Beljak-Beljak Pažinová 2018, 215; Beljak-Beljak Pažinová-Šimkovic 2018, 46, 48; Hanuliak-Hunka 2000, 364, 365).

Záverom môžeme konštatovat', že systematický výskum Horného Pustého hradu prináša nielen detailnejšiu identifikáciu stavebných etáp královského sídla (bližšie predstavenie lokality a výskumu pozri Beljak Pažinová-Beljak 2020), ale postupným cieleným odkrývaním hradného areálu sa darí lepšie interpretovat' život a aktivity samotných obyvatelov v priebehu 13. a 14. storočia, na čo poukázal aj predstavený jedinečný fond kovovej miniatúry.

Práca bola podporená Agentúrou na podporu výskumu a vývoja na základe zmluvy č. APVV-0063-17 Vita intra muros - interdisciplinárny výskum hradov stredného Slovenska.

prof. PhDr. Noémi Beljak Pažinová, PhD., Katedra archeológie Filozofickej fakulty Univerzity Konštantína Filozofa v Nitre, Tr. A. Hlinku 1, 94901 Nitra, Slovenská republika, nbpazinova@ukf.sk

PhDr. Radoslav Ragač, PhD., Pamiatkový úrad SR, Cesta na Červený most 6, 81104 Bratislava, Slovenská republika,radoslav.ragac@pamiatky.gov.sk

PhDr. Ján Beljak, PhD., Archeologický ústav Slovenskej akadémie vied v Nitre, Vysunuté pracovisko vo Zvolene, Štúrova 2, 96001 Zvolen, Slovenská republika,jan.beljak@savba.sk 